\title{
Remineralization of organic matter and degradation of the organic fraction of suspended solids in the River Danube
}

\author{
Birgit Hoch ${ }^{1}$, Barbara Berger ${ }^{1}$, Gerhard Kavka ${ }^{2}$, Gerhard J. Herndl ${ }^{1, *}$ \\ ${ }^{1}$ Institute of Zoology, University of Vienna, Althanstr. 14, A-1090 Vienna, Austria \\ ${ }^{2}$ Federal Institute of Water Quality, Schiffmühlenstr. 120, A-1220 Vienna, Austria
}

\begin{abstract}
To determine the role of microbes in the degradation of organic matter in the River Danube, the biochemical oxygen demand (BOD) was followed over 2 and $5 \mathrm{~d}$ from July to December 1993, and the fluctuations of the microbial community were monitored in incubation flasks over the incubation periods of 2 and $5 \mathrm{~d}$ from January to December 1993. In the BOD flasks, bacterial abundance increased by up to $63 \%$ of the initial abundance during the first $15 \mathrm{~h}$ of incubation followed by an increase in flagellates, reaching their maximum about $35 \mathrm{~h}$ after starting the incubation. After $60 \mathrm{~h}$, bacterial abundance declined to $15 \%$ of the initial density. This rapid fluctuation indicates that the BOD method routinely used to monitor water quality may be inappropriate for measuring the degradability of organic matter since the confined bacterial community is efficiently controlled by flagellates. The role and degradability of the organic coating of suspended solids was evaluated by Alcian blue staining and transmission light microscopy. Degradation experiments revealed that the number of particles decreased by up to $50 \%$ during the incubation period indicating rapid microbial utilization of this particulate matter.
\end{abstract}

KEY WORDS: River Danube $\cdot$ Large river $\cdot$ Particle $\cdot$ Bacteria $\cdot$ Flagellates $\cdot$ BOD $\cdot$ Seston $\cdot$ Degradation

\section{INTRODUCTION}

The role of bacterioplankton in carbon and energy flow through aquatic systems has been an area of intense research during the last decade (Azam et al. 1983). This research has shown that heterotrophic bacteria dominate system metabolism in marine as well as freshwater systems, converting dissolved and particulate organic matter into bacterial biomass and inorganic carbon (Cho \& Azam 1988, Cole et al. 1988, Hobbie 1988, Pomeroy \& Wiebe 1988, Billen et al. 1990). Despite these advances in the understanding of the ecological role of bacteria in aquatic systems and in the food web, a considerable gap in our knowledge of the microbial ecology of lotic systems still exists (Leff 1994).

\footnotetext{
- Addressee for correspondence

E-mail: gerhard.herndl@univie.ac.at
}

Large river systems such as the River Danube are characterized by a high load of suspended solids. Riverine bacteria may occur either in a free-living or a particle-attached mode. Although the attachment to surfaces is commonly believed to be of advantage for bacteria, often only a minor fraction of the bacterial community actually colonizes the available surface of suspended particles (Hoppe 1984, Iriberri et al. 1990). Particulate matter has the ability to adsorb dissolved organic matter (DOM), ions or cell debris, thus leading to a micro-spatial accumulation of nutrients (PedrósAlió \& Brock 1983). It has been shown, predominately for marine systems, that particles are sites of increased heterotrophic activity (Laanbroek \& Verplanke 1986 Almeida \& Alcântara 1992). Despite the high concentrations of suspended solids in lotic systems, information on bacteria-particle interactions is mainly available for marine and lentic systems, whereas large rivers have received little attention. 
In this study the relation between the heterotrophic bacterial community and the number and degradation of the suspended particles was examined in the River Danube over a semi-annual cycle. Particles were stained with Alcian blue, a specific polysaccharide stain which allowed us to distinguish between inorganic particles and/or the extent of organic coating of inorganic particles. To evaluate the ability of heterotrophic bacteria to utilize and decompose this organic coating of particles, laboratory experiments were performed. Based on these experiments and on bacterial production measurements, we estimated the trophic role of these particles in the overall system metabolism.

In addition to these experiments, the microbial fluctuations in flasks commonly used to estimate the biochemical oxygen demand (BOD) were determined. BOD is a basic parameter routinely used in water quality control and is thought to provide information on the amount and degradability of organic matter (American Public Health Association 1989). Generally, water is confined in Winkler bottles, usually at $20^{\circ} \mathrm{C}$ for 2 or $5 \mathrm{~d}$. However, it is well known from microcosm experiments that both bacteria and flagellates undergo large fluctuations in abundance during periods of confinement (Andersson \& Fenchel 1985, Bloem et al. 1988, Berninger et al. 1991). By following the dynamics in bacteria and flagellate abundance, we aimed to test the validity of the method as a means of measuring degradability of organic matter.

\section{MATERIAL AND METHODS}

Sampling sites. Water samples were taken from the right bank ( $2 \mathrm{~m}$ from bank at $0.2 \mathrm{~m}$ depth) of the River Danube at 6 different sampling sites at bimonthly intervals in 1993. One sampling station (Stn 1) was located upstream of the city of Vienna, Austria, and 4 sampling sites were downstream (Stns 3 to 6; Fig. 1). An additional site ( $\operatorname{Stn} 2$ ) was just below the outlet of Vienna's sewage treatment plant in the River Danube Canal. The samples were collected in combusted $\left(450^{\circ} \mathrm{C}\right.$ for $\left.4 \mathrm{~h}\right)$ sterile glass bottles and brought back to the laboratory in a dark insulated box within $1.5 \mathrm{~h}$. Water temperature was measured during sampling.

Particle degradation experiments. Since inorganic particles with an organic coating in the size range 2 to $15 \mu \mathrm{m}$ in diameter were abundant in these waters, laboratory experiments were performed with water

from 2 selected sites (Stns 1 and 2) from August to December 1993. Water from the respective sampling site was incubated in combusted Winkler bottles and placed on a laboratory shaker at $20^{\circ} \mathrm{C}$ in the dark for $5 \mathrm{~d}$. At varying sampling intervals ( 2 to 12 h) 2 flasks were opened and sampled: one flask was used to enumerate the abundance of particles, heterotrophic bacteria and flagellates, the other flask was fixed with formaldehyde $(2 \%, v / v$ final concentration $)$ and served as a control.

Parameters measured. Water samples from the 6 stations were processed in the laboratory to enumerate bacteria, flagellates and particles and to determine BOD, dissolved (DOC) and total organic carbon (TOC), and the dry weight (DW) and ash-free dry weight (AFDW) of the particulate fraction as outlined below.

Enumeration of bacteria, flagellates and inorganic particles with organic coating (IPOC): To enumerate free-living bacteria and flagellates, 1 to $5 \mathrm{ml}$ samples were stained with DAPI (working stock concentration $10 \mu \mathrm{g} \mathrm{ml^{-1 }}$ ) following the procedure outlined in Porter \& Feig (1980). To enumerate particle-attached bacteria and IPOC, water samples (1 to $5 \mathrm{ml}$ ) were carefully transferred with a glass tube $(0.3 \mathrm{~mm}$ inner diameter) and double-stained with acridine orange (Hobbie et al. 1977) and Alcian blue. Alcian blue is thought to stain specifically acidic mucopolysaccharides (Decho 1990). Subsamples ( 1 to $5 \mathrm{ml}$ ) were fixed with $0.2 \mu \mathrm{m}$ filtered formaldehyde $(2 \%, \mathrm{v} / \mathrm{v}$ final concentration) and stained with a few drops of an acridine orange solution $(0.2 \mu \mathrm{m}$ filtered) The sample was gently filtered onto a black polycarbonate filter (Millipore GTBP, $0.2 \mu \mathrm{m}, 25 \mathrm{~mm}$ ). Subsequently, 
while still under suction pressure, $300 \mu \mathrm{l}$ of an aqueous Alcian blue solution $10.2 \%$ in $6 \%$ acetic acid, $\mathrm{pH}=2.5,0.2 \mu \mathrm{m}$ filtered) was added onto the wet filter and allowed to stain for $<5 \mathrm{~s}$. The filter was embedded in paraffin oil and the attached bacteria and IPOC were counted with a Leitz Laborlux microscope equipped with a Ploemopak epifluorescence unit. The size of IPOC was determined directly by using an ocular micrometer. The mean area of the IPOC was calculated from the number of IPOC and the longest dimensions multiplied by the mean width of each IPOC. At least 20 IPOC were counted per sample

Biochemical oxygen demand: $\mathrm{BOD}$ was determined for Stns 1 and 2 following the procedure outlined in Parsons et al. (1984) using a Methrom Titrino 702-SM. Winkler flasks ( $250 \mathrm{ml}$ volume) were incubated at $20^{\circ} \mathrm{C}$ in the dark over 2 and $5 \mathrm{~d}\left(\mathrm{BOD}_{2}\right.$ and $\mathrm{BOD}_{5}$ respectively).

Dissolved and total organic carbon: Water for DOC analysis was taken over the entire annual cycle and was filtered through combusted $\left(450^{\circ} \mathrm{C}\right.$ for 4 h) Whatman GF/F filters, while water for TOC analysis was not filtered. Samples for both analyses were stored in sealed and combusted glass ampoules in the dark at $-20^{\circ} \mathrm{C}$. After samples had been brought to room temperature, $100 \mu \mathrm{l}$ was injected into a Beckman Tocamaster 915-B calibrated with anhydrous potassium biphthalate. Inorganic carbon was removed by acidifying the samples to $\mathrm{pH} 2$ with $50 \mu \mathrm{HCl}$. Subsequently the sample was sparged in a stream of synthetic $\mathrm{CO}_{2}$ free air for $5 \mathrm{~min}$. Measurements were performed in triplicate. The coefficient of variation between triplicate measurements was $<10 \%$.

Dry weight and ash-free dry weight: The DW of suspended solids in the water samples was measured over the annual cycle by filtering $500 \mathrm{ml}$ of sample onto combusted $\left(450^{\circ} \mathrm{C}\right.$ for $\left.4 \mathrm{~h}\right)$ and weighed glass fiber filters (Whatman GF/F). Filters were dried at $60^{\circ} \mathrm{C}$ for $48 \mathrm{~h}$ and reweighed. For the determination of AFDW, filters were combusted at $450^{\circ} \mathrm{C}$ for $4 \mathrm{~h}$. AFDW was estimated from the weight loss on ignition.

\section{RESULTS}

\section{Bacterial and flagellate abundance}

At Stn 1 (River Danube), mean bacterial abundance was $3.9 \times 10^{6} \mathrm{ml}^{-1}(\mathrm{SD}=2.1, \mathrm{n}=22)$ and therefore about 3 orders of magnitude higher than flagellate abundance (mean $=4.6 \times 10^{3} \mathrm{ml}^{-1}, \mathrm{SD}=2.3, \mathrm{n}=19$ ) (Fig. 2). While flagellate abundance was highest in spring, bacterial abundance showed no clear seasonal trend. At Stn 2 (River Danube Canal) mean bacterial abundance
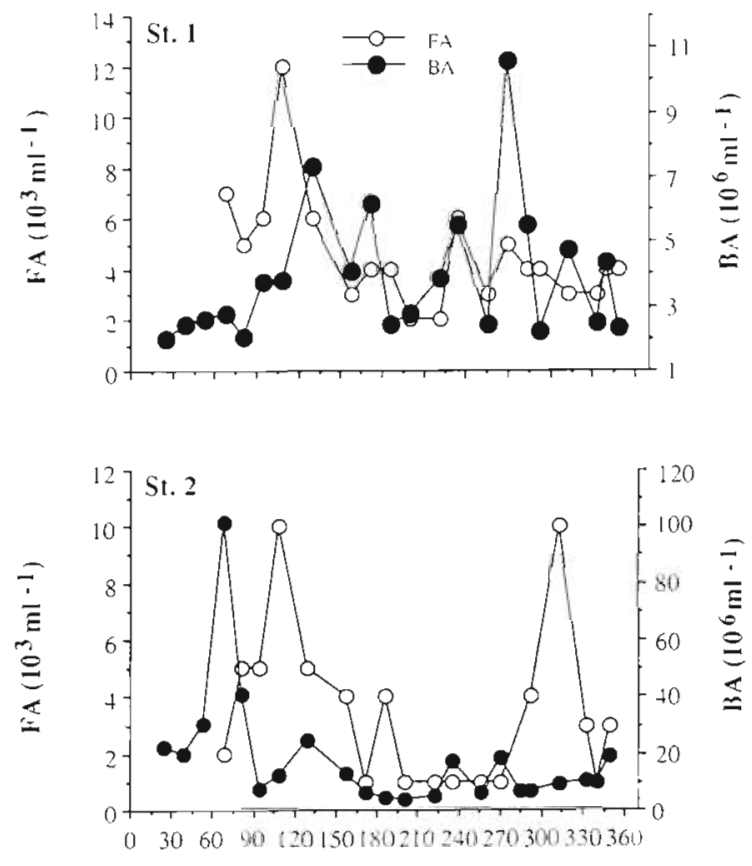

day of 1993

Fig. 2. Bacterial (BA) and flagellate (FA) abundance at Stns 1 and 2 during 1993

was about 4.5 times higher than at Stn 1 (mean $=18 \times$ $10^{6} \mathrm{ml}^{-1}, \mathrm{SD}=20.9, \mathrm{n}=22$ ). While flagellate abundance was significantly lower (mean $=3.3 \times 10^{3} \mathrm{ml}^{-1}$, Wilcoxon test, $\mathrm{p}=0.009, \mathrm{n}=18$ ) than at Stn 1 (Fig. 2), no correlation was found between bacterial and flagellate abundance.

\section{DOC and TOC}

At Stn 1, DOC and TOC averaged $3.4 \pm 1.01( \pm \mathrm{SD})$ and $3.9 \pm 1.3 \mathrm{mg} \mathrm{Cl}^{-1}$, respectively, with highest concentrations shortly after the spring flood and the subsequent phytoplankton bloom (Fig. 3). At Stn 2, approximately 2 times higher DOC and TOC concentrations were found (mean DOC: $6.34 \pm 3.3 \mathrm{mg} \mathrm{Cl}^{-1}$; mean TOC: $8.56 \pm 4.88 \mathrm{mg} \mathrm{Cl}^{-1}$; Fig. 3 ).

\section{Comparison between $\mathrm{BOD}_{2}$ and $\mathrm{BOD}_{5}$}

Oxygen concentration varied between 75 and $100 \%$ of the saturation level at Stn 1 and between 70 and $106 \%$ at Stn 2 with no discernable pattern (data not shown). $\mathrm{BOD}_{2}$ and $\mathrm{BOD}_{5}$ exhibited similar seasonal dynamics at all 6 sampling sites of the River Danube. Therefore only Stn 1 (as representative for the River Danube) and Stn 2 (River Danube Canal) are shown in Fig. 4. At Stn $1, \mathrm{BOD}_{2}$ and $\mathrm{BOD}_{5}$ aver- 

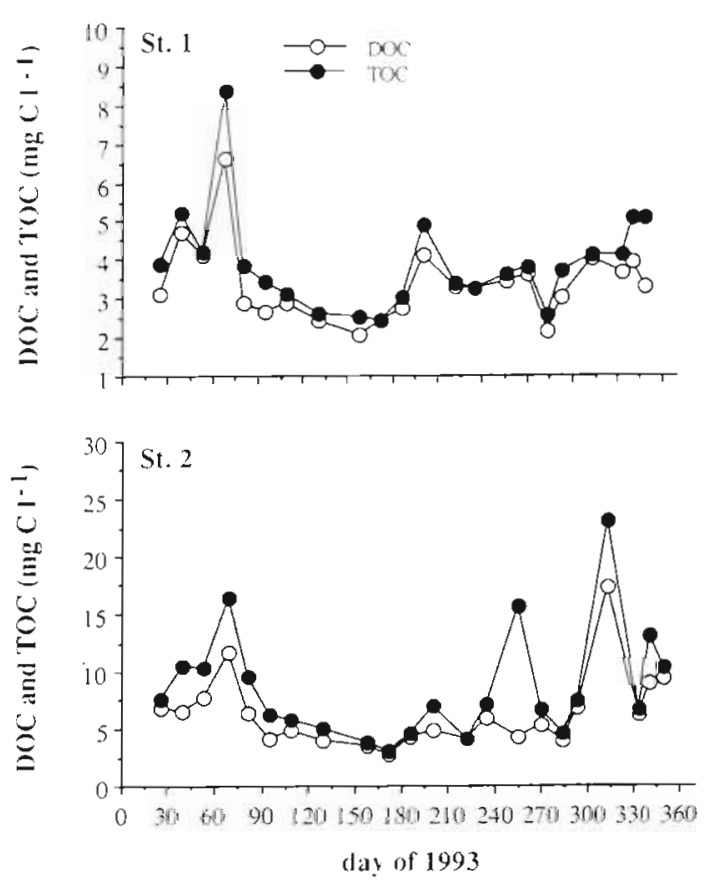

Fig. 3. Dissolved (DOC) and total (TOC) organic carbon concentrations at Stns 1 and 2 during 1993

aged $0.69 \pm 0.34$ and $0.47 \pm 0.23 \mathrm{mg} \mathrm{O}_{2} \mathrm{l}^{-1} \mathrm{~d}^{-1}$, respectively. At $\mathrm{Stn} 2, \mathrm{BOD}_{2}$ (mean: $2.16 \pm 1.27 \mathrm{mg}$ $\mathrm{O}_{2} \mathrm{l}^{-1} \mathrm{~d}^{-1}$ ) was on average also 1.5 times higher than $\mathrm{BOD}_{5}$. Generally, oxygen consumption measured as $\mathrm{BOD}_{2}$ was significantly higher than $\mathrm{BOD}_{5}$ (Wilcoxon test, $\mathrm{p}<0.001, \mathrm{n}=21$ ) and more variable at both sites. The higher oxygen consumption in the $\mathrm{BOD}_{2}$ is reflected by the development of the bacterial abundance in the BOD flasks over a period of $5 \mathrm{~d}$ (Fig. 5). In the initial phase of the BOD incubations both bacterial and flagellate densities increased over $12 \mathrm{~h}$ to $24 \mathrm{~h}$ and after about $2 \mathrm{~d}$, respectively; bacteria and flagellates declined in abundance in the BOD flasks of both sites, Stn 1 and, even more pronounced, Stn 2 (Fig. 5)

\section{Dry weight and ash-free dry weight of suspended solids}

In the River Danube, DW of suspended solids varied between 5 and $20 \mathrm{mg} \mathrm{I}^{-1}$ throughout the year with a pronounced peak ( $\left.80 \mathrm{mg} \mathrm{l}^{-1}\right)$ coinciding with the major flood event in mid July (Day 200). AFDW ranged from 2.2 to $13.2 \mathrm{mg} \mathrm{l}^{-1}$ and remained $<8 \mathrm{mg} \mathrm{l}^{-1}$ throughout most of the year except in summer (data not shown). On average, AFDW comprised $43.3 \pm$ $22.8 \%$ (range: 14.6 to $87.5 \%$ ) of the DW at Stn 1 and $56.8 \pm 26.4 \%$ (range: 13.2 to $92.6 \%$ ) at $\operatorname{Stn} 2$.

\section{Inorganic particles with an organic coating}

In the River Danube, the abundance of IPOC was determined at monthly intervals from August to December 1993; mean IPOC density at the beginning of the incubation period was $3 \pm 1.3 \times 10^{4} \mathrm{ml}^{-1}(\mathrm{n}=5)$ at Stn 1 and $3.02 \pm 1.9 \times 10^{4} \mathrm{mi}^{-1}$ at $\operatorname{Sin} 2$ (data not shown).

IPOC declined over a $5 \mathrm{~d}$ incubation period at $20^{\circ} \mathrm{C}$ in both numbers and total area (Table 1). This tendency was detectable in the biotic and abiotic treatment; decay constants in the abiotic formalin-fixed treatment were about half of those in the biotic treatment (Table 1). Throughout the incubation period, attached bacteria contributed $\sim 10 \%$ (range: 1.25 to
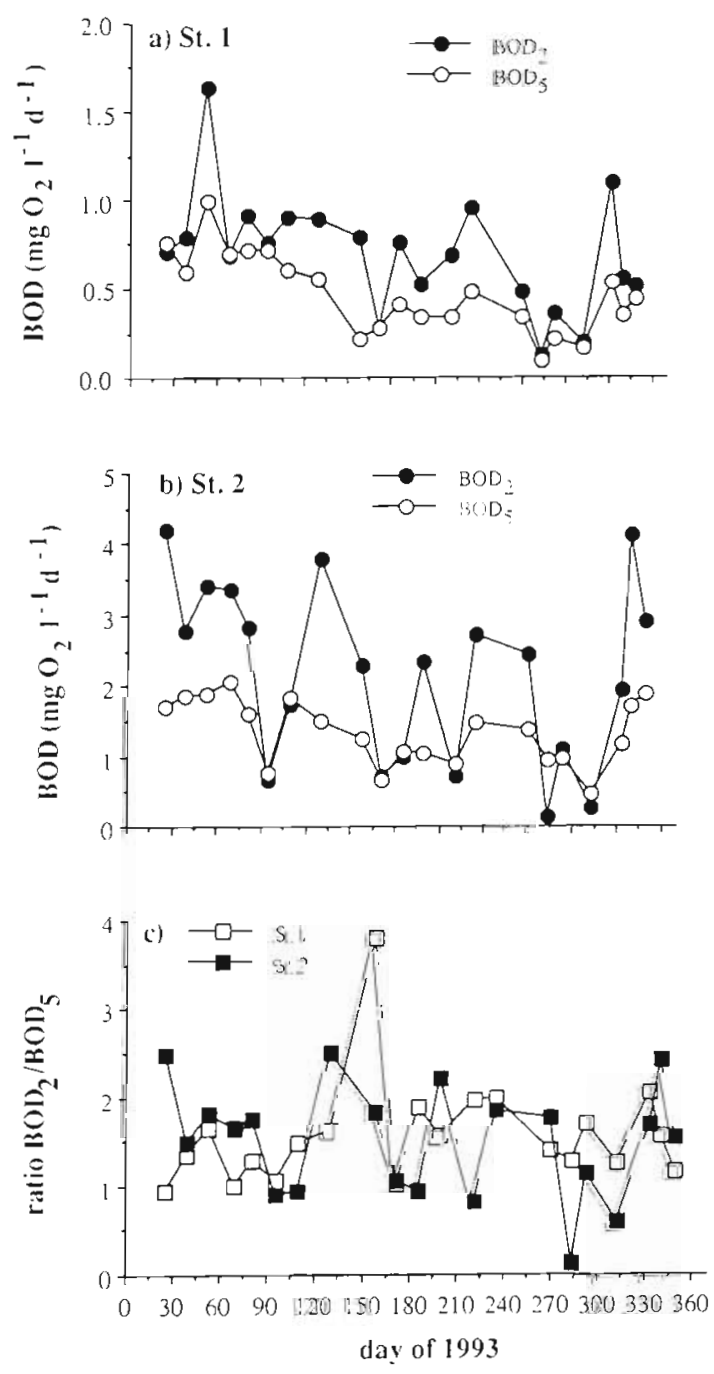

Fig. 4. Biological oxygen demand over 2 and $5 \mathrm{~d}\left(\mathrm{BOD}_{2}\right.$ and $\mathrm{BOD}_{5}$ ) at (a) Stn 1 and (b) Stn 2 during 1993, and (c) the ratio between $\mathrm{BOD}_{2}$ and $\mathrm{BOD}_{5}$ at Stns 1 and 2 

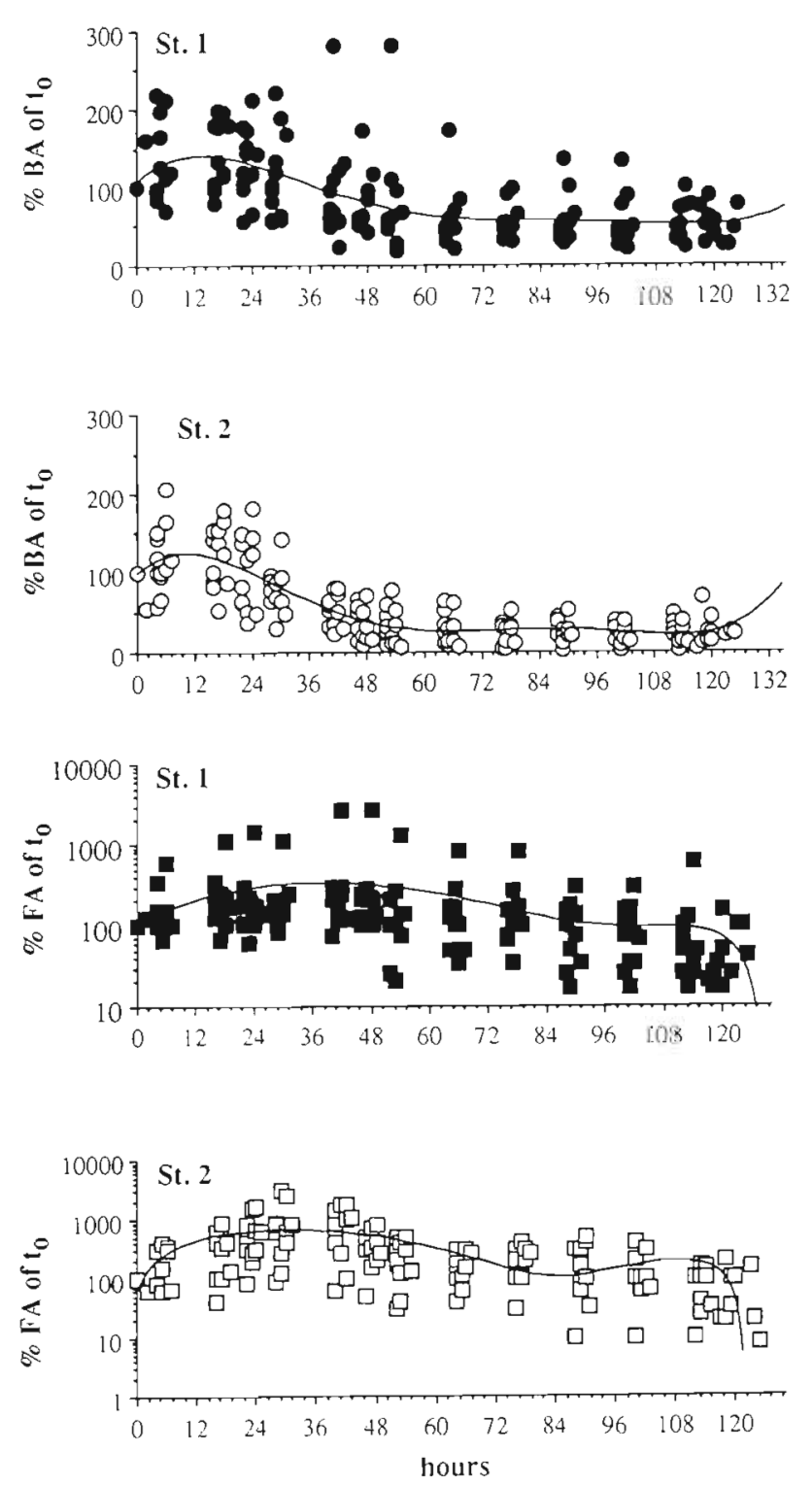

Fig. 5. Bacterial and flagellate abundance in the Winkler flasks over a $5 \mathrm{~d}$ incubation period described as percentage of the intial bacterial and flagellate abundance $\left(\%\right.$ BA of $t_{0} \%$ FA of $t_{0}$ ) at Stns 1 and 2. A total of 12 experiments were performed over the 12 mo investigation period

$23.7 \%$ ) to total bacterial abundance with no difference discernable between biotic and abiotic controls (data not shown); at Stn 2 a similar pattern was found (mean: attached bacteria $8.2 \%$ of total bacterial abundance). Mean surface area of IPOC was $54.0 \pm 21.4 \mu \mathrm{m}^{2}$ at Stn 1 and $59.3 \pm 62.1 \mu \mathrm{m}^{2}$ at Stn 2. No significant decrease in surface area of IPOC was detectable during the incubation period; only at Stn 2 was the surface area of the formalin-fixed controls significantly higher than in the untreated samples (Wilcoxon test, $\mathrm{p}<$ $0.001, n=22$ ).

\section{DISCUSSION}

The decomposition of easily degradable substances can be measured by BOD over 2 or $5 \mathrm{~d}$ under standardized conditions. This parameter is routinely used to assess water quality (American Public Health Association 1989, Klee 1990). As shown in this study (Figs. 4 \& 5), the oxygen consumed is highly dependant on the incubation period. Less oxygen per day is consumed in $\mathrm{BOD}_{5}$ as compared to $\mathrm{BOD}_{2}$ due to the general decline of the microbial abundance after $2 \mathrm{~d}$ of confinement in the Winkler flasks (Fig. 5). In our study no seasonal trend in BOD was discernable, although slightly higher rates were observed during spring (Fig. 4). $\mathrm{BOD}_{5}$ at Stn 1 averaged $0.47 \pm 0.23 \mathrm{mg} \mathrm{O}_{2} \mathrm{l}^{-1} \mathrm{~d}^{-1}$ and is comparable to $\mathrm{BOD}_{5}$ rates of $0.52 \mathrm{mg} \mathrm{O}_{2} \mathrm{l}^{-1} \mathrm{~d}^{-1}$ measured in the River Rhine (Admiraal \& Zanten 1988). Oxygen consumption per day was on average $31.5 \%$ lower in $\mathrm{BOD}_{5}$ than in $\mathrm{BOD}_{2}$ and fell within the range measured in the River Danube by Kavka et al. (1990) for the period 1980 to 1987 . Since chlorophyll a (chl a) concentrations in the River Danube can reach up to $70 \mathrm{\mu g} \mathrm{l}^{-1}$ (Hoch et al. in press), the higher BOD rates during spring could be attributable to the availability of algal exudates which are rapidly taken up by bacteria (Chróst 1986, Baines \& Pace 1991, White 1991). The possibility that autochthonous production can be - at least temporarily - an important carbon and nutrient source for heterotrophic bacteria in large rivers was also mentioned by Descy \& Gosselain (1994). This con-

Table 1. Decay constants $\left(\mathrm{h}^{-1}\right)$ calculated from exponential decay curves at Stns 1 (River Danube) and 2 (River Danube Canal) during 1993. IPOC: inorganic particles with organic coating; tot area: no. of particles in $10^{5} \mathrm{ml}^{-1} \times$ mean area in $\mu \mathrm{m}^{2}$

\begin{tabular}{|c|c|c|c|c|}
\hline \multirow[t]{2}{*}{ Date } & \multicolumn{2}{|c|}{$I P O C$} & \multicolumn{2}{|c|}{ Controls } \\
\hline & No. & Tot. area & No. & Tot. area \\
\hline \multicolumn{5}{|c|}{ Stn 1: River Danube } \\
\hline Aug & -0.00213 & -0.005 & -0.002 & -0.00264 \\
\hline Sept & -0.000347 & -0.0013 & -0.00033 & -0.00176 \\
\hline Oct & -0.00256 & -0.0019 & & -0.000332 \\
\hline Nov & -0.00648 & -0.00394 & -0.000295 & -0.00186 \\
\hline Dec & -0.0089 & -0.00726 & & -0.000436 \\
\hline Mean & -0.0041 & -0.0039 & -0.000874 & -0.00141 \\
\hline $\mathrm{SD}$ & 0.0035 & 0.00241 & 0.001 & 0.001 \\
\hline \multicolumn{5}{|c|}{ Stn 2: River Danube Canal } \\
\hline Aug & -0.00578 & -0.0115 & & \\
\hline Sept & -0.00879 & -0.0127 & & \\
\hline Oct & -0.0026 & -0.00191 & -0.00258 & -0.00385 \\
\hline Nov & -0.00106 & -0.00852 & -0.00154 & \\
\hline Dec & -0.00289 & -0.00131 & & \\
\hline Mean & -0.00422 & -0.00955 & -0.00208 & -0.00385 \\
\hline SD & 0.0031 & 0.0046 & 0.0007 & \\
\hline
\end{tabular}


a) St. 2

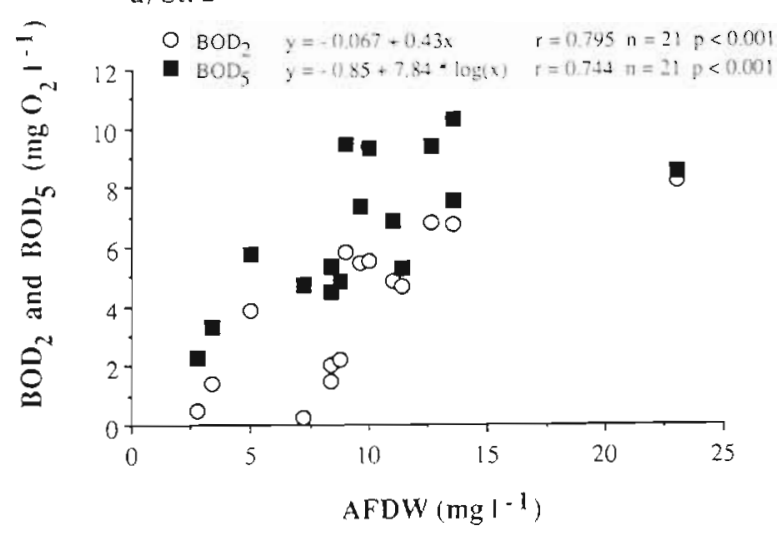

b) St. $1 \quad y=-20.1+0.03 x \quad r=0.859 n=17 p<0.001$

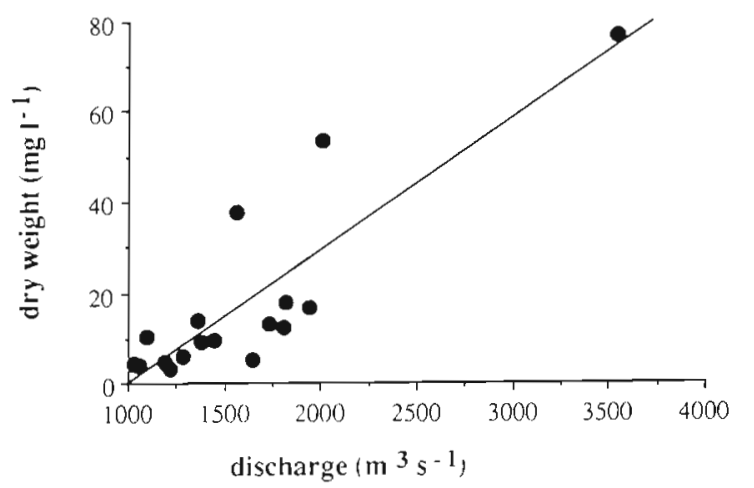

Fig. 6. Correlation between (a) $\mathrm{BOD}_{2}$ and $\mathrm{BOD}_{5}$ and ash-fee dry weight (AFDW) at Stn 2 (Stn 1 not significant) and (b) dry weight and discharge at $\operatorname{Stn} 1$ (for $\operatorname{Stn} 2, \mathrm{r}=0.54, \mathrm{p}<0.02$, data not shown)

tention is also supported by a significant correlation between $\mathrm{BOD}_{2}$ and $\mathrm{BOD}_{5}$ and $\mathrm{chl} a$ in the River Danube $(r=0.545$ and 0.533 , respectively, $n=105, p<$ $0.001_{i}$ data not shown), while at $\operatorname{Stn} 2 \mathrm{BOD}_{2}$ and $\mathrm{BOD}_{5}$ rates showed a significant correlation with AFDW $(\mathrm{r}=$ 0.795 and 0.744, respectively, $\mathrm{n}=16, \mathrm{p}<0.001$; Fig. 6a). This correlation and the about 3 times higher $\mathrm{BOD}_{2}$ (mean: $2.16 \pm 1.27 \mathrm{mg} \mathrm{O}_{2} \mathrm{l}^{-1} \mathrm{~d}^{-1}$ ) and $\mathrm{BOD}_{5}$ (mean: $1.38 \pm 0.46 \mathrm{O}_{2} \mathrm{l}^{-1} \mathrm{~d}^{-1}$ ) suggest the availability of larger amounts of degradable organic matter originating from waste water input.

Although river discharge is one of the most important abiotic factors regulating bacterial activity (via alteration of the amount of suspended and dissolved organic matter), no correlation could be detected between BOD rates and discharge (Kasimir 1992). Fluctuations in suspended matter may influence other important biological and chemical processes such as primary production, ingestion rates of filter feeders, adsorption and desorption of nutrients or pollutants on particles (Findlay et al. 1991). Seston in streams and rivers either originates from production within the water column or from benthic or terrestrial sources. A positive correlation between suspended matter and discharge and a negative correlation between phytoplankton biomass and discharge were found by Kiss et al. (1994) in the River Danube. We obtained a positive correlation between discharge and DW for $\operatorname{Stn} 1(\mathrm{r}=0.859, \mathrm{n}=$ 17, $p<0.001$; Fig. 6b) but only a poor correlation between these parameters for $\operatorname{Stn} 2(r=0.54, n=17, p$ $<0.02$; data not shown). In our study, DW ranged from 3.2 to $76.8 \mathrm{mg} \mathrm{l}^{-1}$; these concentrations are in good agreement with those of Schmidt (1994), who determined a total solid content in the River Danube of between 10 and $100 \mathrm{mg} \mathrm{l}^{-1}$ when discharge was below $3500 \mathrm{~m}^{3} \mathrm{~s}^{-1}$. Thus the dry weight of the suspended solids in the River Danube is about 2 times lower than that found by Admiraal \& Zanten (1988) in the lower River Rhine, but comparable to the concentration of suspended solids of $16.9 \mathrm{mg} \mathrm{l}^{-1}$ in the Hudson River (Findlay et al. 1991). AFDW increased after periods of high discharge rates, although no correlation between BOD and discharge rates has been found; thus we conclude that mostly recalcitrant material, presumably of soil origin, is swept into the river during flood events. In residing waters, bacteria utilize the introduced allochthonous organic and inorganic substances.

At Stn 1, DOC concentrations averaged $3.4 \mathrm{mg} \mathrm{C} \mathrm{l}^{-1}$ and were about 2 times higher at Stn 2 . These concentrations are comparable to those found in other freshwater systems (Admiraal \& Zanten 1988, Berninger et al. 1991, Findlay et al. 1991, Carlough 1994). By converting measured $B O D$ rates to carbon equivalents, we were able to roughly estimate DOC turnover rates; these rates are biased, however, by the constant temperature used $\left(20^{\circ} \mathrm{C}\right)$ and the long incubation period ( 2 d) used for calculating the respiration. At Stns 1 and 2, DOC turnover rates ranged from 0.02 to 0.15 and 0.01 to $0.36 \mathrm{~d}^{-1}$, respectively.

The ratio between $\mathrm{BOD}_{2}$ and $\mathrm{BOD}_{5}$ was on average 1.5 at both stations but showed pronounced fluctuations over the annual cycle (Fig. 4c). A ratio near 1 was only obtained when oxygen consumption was low. This indicates that labile substances were taken up within $2 \mathrm{~d}$ during periods of low overall concentrations and that the larger pool of refractory substances was not utilized in significant amounts. During periods of generally high remineralization activity, the abundance of more refractory compounds led to a lower percentage of DOC being utilized by the bacterial community and hence to lower oxygen consumption in $\mathrm{BOD}_{5}$. It is commonly believed that the small fraction of directly accessible DOC is rapidly cycled in aquatic environments (Cole et al. 1982, Kirchman et al. 1991, Leff \& Meyer 1991, Coffin et al. 1993, Sabater et al. 1993, Tranvik 1993, 1994). 
These estimates are, however, influenced by the dynamics of the bacteria confined in the Winkler flasks. In the water of the River Danube (Stn 1), bacterial abundance increased on average by $63 \%$ within 18 h of incubation (Fig. 5). Coffin et al. (1993) detected the highest increase in bacterial numbers during the first $11 \mathrm{~h}$ in their microcosm experiments. The rapid increase in bacterial numbers was followed by a decrease while flagellate densities increased concurrently. After 2 to $3 \mathrm{~d}$ of incubation - or $16 \mathrm{~h}$ after the maximum in bacterial abundance - flagellates reached their highest abundance (Fig. 5). Stn 2 showed similar predator-prey dynamics but exhibited a smaller increase in bacterial abundance (on average $42.6 \%$ of the initial bacterial abundance after 15 h; Fig. 5). Nevertheless, flagellates increased by a factor of 6.4 at Stn 2 compared to 3.6 at Stn 1. After 60 h of incubation, only $28 \%$ of the initial bacterial abundance was present in the incubations of water from Stn 1 and $15.4 \%$ in waters from $\operatorname{Stn} 2$. The conclusion that bacteria are able to utilize the labile pool of organic matter in a relatively short time was also drawn by Coffin et al. (1993) in BOD experiments. Based on the decline in bacterial abundance and the increase in flagellate numbers, we can provide a crude estimate of mean specific grazing rates; 21.3 bacteria flagellate ${ }^{-1} h^{-1}$ at Stn 1 and 40.3 bacteria flagellate ${ }^{-1} \mathrm{~h}^{-1}$ at Stn 2 . Grazing rates in the River Danube are in good agreement with the rate of 16 to 18 bacteria flagellate ${ }^{-1} \mathrm{~h}^{-1}$ given in Carlough \& Meyer (1990) and with the mean grazing rate of 17.3 bacteria flagellate ${ }^{-1} \mathrm{~h}^{-1}$ based on 40 different studies of rivers (Vaqué et al. 1994). In the latter study it was mentioned that grazing rates are higher in rivers than in lakes or marine systems. Nevertheless, specific grazing rates in aquatic systems and cultures are found to vary over a wide range (Fenchel 1982). The nearly 2 times higher grazing rate at Stn 2 could be attributable to the 4 times higher bacterial abundance; in addition, large bacteria, probably originating from the effluent of the sewage treatment plant, were readily detectable. It has been documented in many studies that flagellates preferentially graze on larger prey and may therefore control the size distribution of bacteria; smaller cells may benefit from lower grazing pressure (Chrzanowski \& Simek 1990, Psenner \& Sommaruga 1992, Sherr et al. 1992, Simek \& Chrzanowski 1992). The predominance of small bacteria $\left(0.24 \mu \mathrm{m}^{3}\right.$; Kasimir 1992) and a high flagellate abundance (mean: $4.6 \times$ $10^{3} \mathrm{ml}^{-1}$ ) in the River Danube support this conclusion. The flagellate abundance found in this study is in good agreement with that reported by Kasimir (1992) (range: 1 to $22 \times 10^{3} \mathrm{ml}^{-1}$ ); similarly, Carlough \& Meyer (1989) found $11 \times 10^{3}$ flagellates $\mathrm{ml}^{-1}$ in the Ogeechee River. Despite high flagellate numbers commonly occurring in rivers, Fenchel (1986) noted that protists are not important in lotic systems because of high wash-out rates. Calculating the community grazing rate for the River Danube according to Carlough \& Meyer (1989) and assuming a clearance rate of $10^{-8} \mathrm{l}$ flagellate ${ }^{-1} \mathrm{~h}^{-1}$ (Andersson \& Fenchel 1985), $44.4 \times$ $10^{5}$ cells $\mathrm{ml}^{-1} \mathrm{~d}^{-1}$ are grazed. Converting this grazing rate into carbon equivalents (assuming a carbon content of $20 \mathrm{fg} \mathrm{cell}^{-1}$; Lee \& Fuhrman 1987), $88.8 \mu \mathrm{g} \mathrm{C} \mathrm{l}^{-1}$ $\mathrm{d}^{-1}$ are consumed, which is close to the mean bacterial

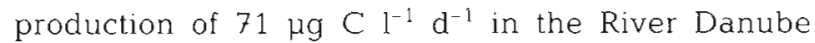
Despite the uncertainties in these calculations the similar rates for community grazing and bacterial production lead us to conclude that the bacterial community is efficiently controlled by protist grazing.

In recent years the origin, distribution and role of organic particles in marine and freshwater systems have received considerable attention (Isao et al. 1990, Wells \& Goldberg 1991, Leppard 1992, Perret et al. 1993). Seston particles, including both organic and inorganic components, influence the structure and function of aquatic systems. Generally, attachment to aggregates of different size is believed to be advantageous for bacteria (Hoppe 1984). Seston particles are important sites for microbial growth, grazing and nutrient regeneration (Pedrós-Alió \& Brock 1983, Goldman 1984). Despite these advantages only around $10 \%$ of bacteria (range: 1.25 to $23.7 \%$ ) were found attached to aggregates, which corresponds to earlier findings (Ducklow \& Kirchman 1983, Hoppe 1984, Almeida \& Alcântara 1992). For the River Danube, a high amount of total seston particles - including clay particles and IPOCs - has been reported by Berger et al. (in press) $\left(1.27 \times 10^{5} \mathrm{ml}^{-1}\right)$, but only $46.8 \%$ of them were colonized by bacteria. Particle colonization might be dependent on the number of particles, their physico-chemical properties and the resulting adsorption capacities. In our study, emphasis was laid on the small fraction of total suspended particles with inorganic nuclei surrounded by an organic coating as revealed by Alcian blue staining. This organic coating is also responsible for glueing several of these discrete particles together, forming larger units with dimensions of several $\mu \mathrm{m}$

In order to investigate the susceptibility of these particles to bacterial degradation, we followed their decay over a $5 \mathrm{~d}$ period. In the River Danube, about $50 \%$ of the initially present IPOC disappeared within $5 \mathrm{~d}$ (see also Table 1); a very similar trend was observed when the total area of IPOC (i.e. number of IPOC in $10^{5} \mathrm{ml}^{-1} \times$ mean area in $\mu \mathrm{m}^{2}$ ) was considered (Table 1). At Stn 2, IPOC declined on average by $67 \%$ within $5 \mathrm{~d}$. The faster decay of IPOC at Stn 2 might be caused by their originating predominately from the sewage treatment plant and their higher organic content; the increased availability of these IPOC is further indi- 
cated by the larger bacteria usually attached to these particles.

Interestingly, total area increased at the beginning of our incubation experiments in waters from both stations (Fig. 7). This might be caused by aggregation of smaller aggregates. Electron microscopy observations generally reveal a predominately fibrillar matrix of aggregates (Leppard 1992, Carlough 1994) At both stations $-10 \%$ of the bacterial community was found attached to particles, which is in good agreement with
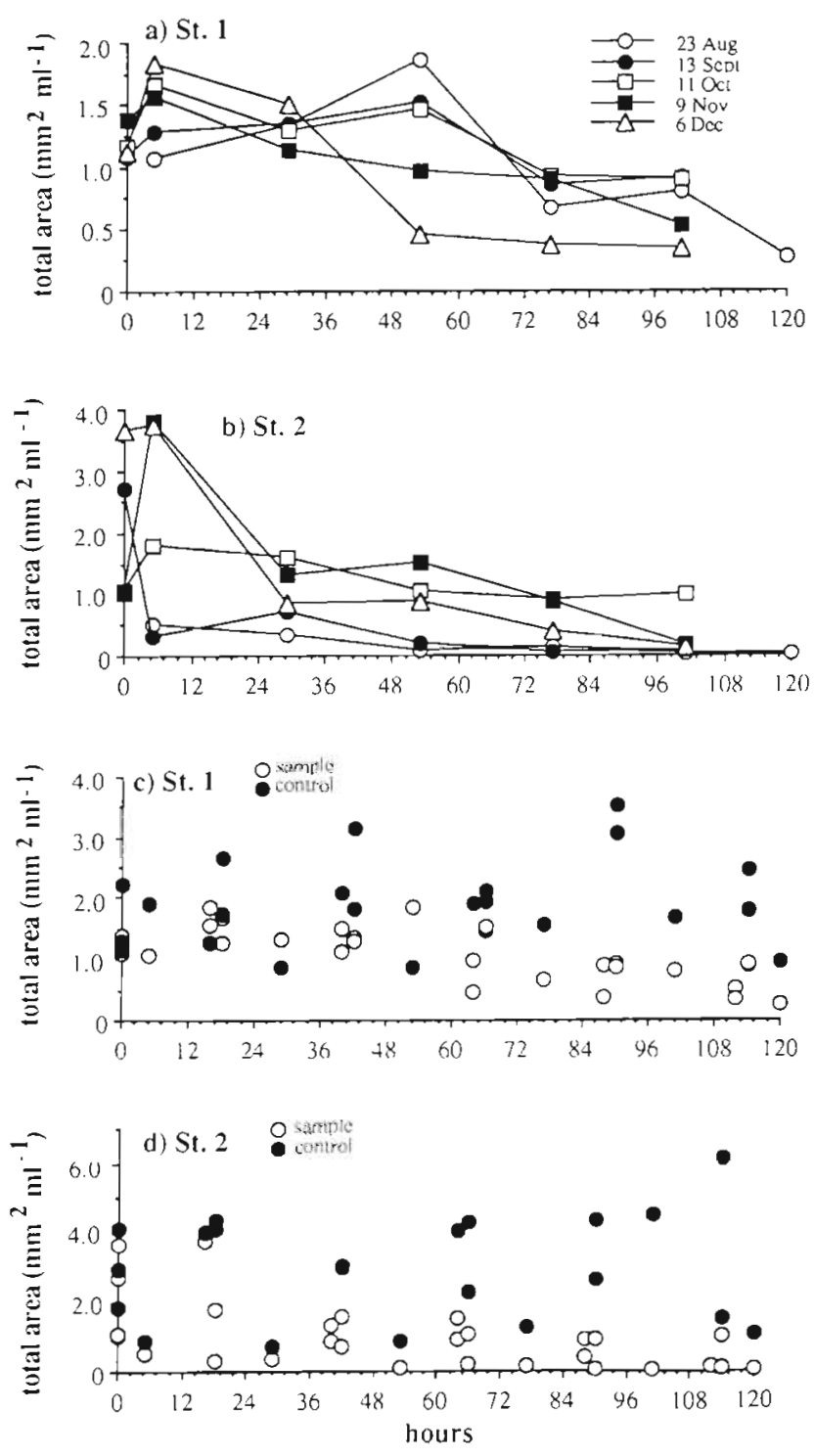

Fig. 7 Total area of inorganic particles with organic coating (IPOC) (mean area of IPOC $\times$ no. of IPOC $\mathrm{ml}^{-1}$ ) at Stns (a) 1 and (b) 2 dunng degradation experiments and the comparison to formaldehyde fixed controls at Stns (c) 1 and (d) $2_{i}$ experiments were performed on different dates as indicated in (a) findings of Ducklow \& Kirchman (1983) and Almeida \& Alcântara (1992). Bacteria colonizing these particles start to utilize labile organic material and simultaneously solubilize the organic matrix of the aggregates. Attached bacteria exhibit higher metabolic activities, growth rates and cell sizes (Pedrós-Alió \& Brock 1983). A fraction of the hydrolyzed products might escape incorporation by attached bacteria, thus their freeliving counterparts might benefit from a surplus of organic matter as supposed by Hoppe et al. (1988). In our incubation experiments, after $\sim 30 \mathrm{~h}$ free-living as well as attached bacteria were grazed by an active flagellate community. After about $70 \mathrm{~h}$ of incubation, the number and total area of IPOC and bacterial and flagellate numbers were low. Since we found no clear decrease of IPOC in the formalin-fixed controls, we conclude that the bacterial community is mainly responsible for colonization and the following decay of the organic matrix of IPOC over a relatively short time span.

\section{CONCLUSION}

We have shown that prey-predator oscillations occur in Winkler flasks during BOD incubations, making the results of this commonly applied method to determine the degradability of organic matter questionable for use in water quality assessments. The initial $3 \times 10^{4}$ IPOC $\mathrm{ml}^{-1}$ decreased by up to $67 \%$ during the $5 \mathrm{~d}$ of incubation, most likely due to microbial solubilization of these particles.

Acknowledgements. We thank the staff of the Federal Institute for Water Quality for their invaluable assistance during field and laboratory work. Financial support was provided by the Austrian National Bank (project no. 4506) and the Austrian Science Foundation (FWF grant no. 8608). The work is in partial fulfillment of the requirements towards a Ph.D. degree at the University of Vienna by B.H. and B.B.

\section{LITERATURE CITED}

Admiraal W, Zanten BV (1988) Impact of biological activity on detritus transported in the lower river Rhine: an exercise in ecosystem analysis. Freshwat Biol 20:215-225

Almeida MA, Alcàntara F (1992) Bacterial colonizatıon of seston particles in brackish waters (Rle de Aveiro, Portugal) Mar Ecol Prog Ser 89:165-173

American Public Health Association (1989) Standard methods for the examination of water and waste water American Public Health Association, Washington, DC

Andersson P, Fenchel $T$ (1985) Bacterivory by microheterotrophic nanoflagellates in seawater samples. Limnol Oceanogr 30:198-202

Azam F, Fenchel T, Field JG, Cray JS, Meyer-Reil LA Thingstad F (1983) The ecological role of water column mucrobes in the sea. Mar Ecol Prog Ser 10:257-263 
Baines SB, Pace ML (1991) The production of dissolved organic matter by phytoplankton and its importance to bacteria: patterns across marine and freshwater systems. Limnol Oceanogr 36:1078-1090

Berger B, Hoch BM, Kavka G, Herndl GJ (in press) Bacterial colonization of suspended solids in the Danube River. Aquat microb Ecol

Bernnger UG, Finlay BJ, Kuuppo-Leinıki P (1991) Protozoan control of bacterial abundances in freshwater Limnol Oceanogr 36:139-147

Billen G. Servais P. Becquevort S (1990) Dynamics of bacterioplankton in oligotrophic and eutrophic aquatic environments: bottom-up or top-down control? Hydrobiologia 27: $37-42$

Bloem J, Starınk M, Bär-Gilissen MJB, Cappenberg TE (1988) Protozoan grazing, bacterial activity, and mineralization in two-stage continuous cultures. Appl environ Microbiol 54: $3113-3121$

Carlough LA (1994) Origins, structure, and trophic significance of amorphous seston in a blackwater river. Freshwat Biol 31:227-237

Carlough LA, Meyer JL (1989) Protozoans in two southeastern blackwater rivers and their importance to trophic transfer. Limnol Oceanogr 34:163-177

Carlough LA, Meyer JL (1990) Rates of protozoan bacterivory in three habitats of a southeastern blackwater river. N Am Benthol Soc 9:45-53

Cho BC, Azam F (1988) Major role of bacteria in biogeochemical fluxes in the ocean's interior. Nature 332:441-443

Chróst RJ (1986) Algal-bacterial metabolic coupling in the carbon and energy cycle of lakes. In: Megusar F, Ganter F (eds) Perspectives in microbiology. Slovene Society for Microbiology, Ljubljana, p 360-366

Chrzanowski TH. Simek K (1990) Prey-size selection by freshwater flagellated protozoa. Limnol Oceanogr 35: $1429-1436$

Coffin BR, Conolly JP, Harris PS (1993) Availability of dissolved organic carbon to bacterioplankton examined by oxygen utilization. Mar Ecol Prog Ser 101:9-22

Cole JJ, Likens G, Strayer D (1982) Photosynthetically produced dissolved organic carbon: an important carbon source for planktonic bacteria. Limnol Oceanogr 27:1080-1090

Cole JJ, Findlay S, Pace ML (1988) Bacterial production in fresh and saltwater ecosystems: a cross-system overview. Mar Ecol Prog Ser 43:1-10

Decho AW (1990) Microbial exopolymers secretions in ocean environments; their role(s) in food webs and marine processes. Ocean mar Biol A Rev 28:73-153

Descy JP, Gosselain V (1994) Development and ecological importance of phytoplankton in a large lowland river (River Meuse, Belgium). Hydrobiologia 289:139-155

Ducklow HW, Kirchman DL (1983) Bacterial dynamics and distribution during a spring diatom bloom in the Hudson River plume, USA. J Plankton Res 5:333-355

Fenchel T (1982) Ecology of heterotrophic microflagellates. II. Bioenergetics and growth. Mar Ecol Prog Ser 8:225-231

Fenchel T (1986) Ecology of protozoa, the biology of freeliving phagotrophic protists. Springer-Verlag, Berlin

Findlay S, Pace M, Lints D (1991) Variability and transport of suspended sediment, particulate and dissolved organic carbon in the tidal freshwater Hudson River. Biogeochemistry 12:149-169

Goldman JC (1984) Conceptual role for microaggregates in pelagic waters. Bull mar Sci 35:462-476

Hobbie JE (1988) A comparison of the ecology of planktonic bacteria in fresh and salt water. Limnol Oceanogr 33: $750-764$
Hobbie JE, Daley RJ, Jasper S (1977) Use of Nucleopore filters for counting bacteria by epifluorescence microscopy. Arch Hydrobiol 107:1-21

Hoch BM, Berger B, Kavka G, Herndl GJ (in press) Influence of waste water treatment on the microbial communty of a large, temperate river system - the River Danube. Hydrobiologia

Hoppe HG (1984) Attachment of bacteria: advantage or disadvantage for survival in the aquatic environment. In: Marshall KC (ed) Microbial adhesion and aggregation. Springer-Verlag, Berlin, p 283-301

Hoppe HG, Kim SJ, Gocke K (1988) Mıcrobial decomposition in aquatic environments: combined process of extracellular enzymatic activity and substrate uptake. Appl environ Microbiol 54:784-790

Iriberri J, Unanue M, Ayo B, Barcina I, Egea L (1990) Attached and free-living dividing bacteria in two aquatic systems. Lett appl Microbiol 11:87-89

Isao K, Hara S, Terauchi K, Kogure K (1990) Role of submicrometre particles in the ocean. Nature 345:242-243

Kasimir GD (1992) Microbial investigations in the River Danube: measuring microbial activities and biomass. Arch Hydrobiol Suppl 84:101-114

Kavka G, Ludwig C, Ranner H, Humpesch UH, Kohl W \{1990\} Langzeitänderungen der Güte der Donau im Raum Wien (Stromkilometer 1934-1902). Österr Wasserwirtschaft 42: $26-36$

Kirchman DL, Suzuki Y, Garside C, Ducklow HW (1991) High turnover rates of dissolved organic carbon during a spring phytoplankton bloom. Nature 352:612-614

Kiss KT, Àcs É, Kovács A (1994) Ecological observations on Skeletonema potamos (Weber) Hasle in the River Danube, near Budapest (1991-92, daily investigations). Hydrobiologia $289: 163-170$

Klee O (1990) Wasser untersuchen: einfache Analysemethoden und Beurteilungskriterien. Quelle und Meyer-Verlag, Heidelberg-Wiesbaden

Laanbroek HJ, Verplanke JC (1986) Seasonal changes in percentage of attached bacteria enumerated in a tidal and stagnant coastal basin: relation to bacterioplankton productivity. FEMS Microbiol Ecol 38:87-98

Lee S, Fuhrman JA (1987) Relationship between biovolume and biomass of naturally derived marine bacterioplankton. Appl environ Microbiol 53:1298-1303

Leff LG (1994) Stream bacterial ecology: a neglected field? ASM News 60:135-138

Leff LG, Meyer JL (1991) Biological availability of dissolved organic carbon along the Ogeechee River. Limnol Oceanogr 36:315-323

Leppard GG (1992) Size, morphology and composition of particulates in aquatic ecosystems: solving speciation problems by correlative electron microscopy. Analyst 117 . $595-603$

Parsons T, Maita X, Lalli C (1984) A manual for chemical and biological methods for seawater analysis. Pergamon Press, Oxford, p 173

Pedrós-Alió C, Brock TD (1983) The importance of attachment to particles for planktonic bacteria. Arch Hydrobiol 98:354-379

Perret D, Newman ME, Negre JC, Chen Y, Buffle J (1993) Submicron particles in the Rhine River - I. Physico-chemical characterization. Wat Res 28:91-106

Pomeroy LR, Wiebe WJ (1988) Energetics of microbial food webs. Hydrobiologia 159:7-18

Porter KG. Feig YS (1980) The use of DAPI for identifying and counting aquatic microflora. Limnol Oceanogr 25:943-948

Psenner R, Sommaruga R (1992) Are rapid changes in bacter- 
ial biomass caused by shifts from top-down to bottom-up control? Limnol Oceanogr 37:1092-1100

Sabater F. Meyer JL, Edwards RT (1993) Longitudinal patterns of dissolved organic carbon concentration and suspended bacterial density along a blackwater river. Biogeochemistry 43:1-21

Schmidt A (1994) Main characteristics of the phytoplankton of the southern Hungarian section of the River Danube. Hydrobiologia 298:97-108

Sherr BF, Sherr EB, McDaniel J (1992) Effect of protistan grazing on the frequency of dividing cells in bacterioplankton assemblages. Appl environ Microbiol 58:2381-2385

Simek K, Chrzanowski TH (1992) Direct and indirect evidence of size-selective grazing on pelagic bacteria by freshwater nanoflagellates. Appl environ Microbılol 58:3715-3720

Responsible Subject Editor: J. Dolan, Villefranche-sur-Mer, France
Tranvik LJ (1993) Microbial transformation of labile dissolved organic matter into humic-like matter in seawater FEMS Microbılol Ecol 12:177-1.83

Tranvik LJ (1994) Colloidal and dissolved organic matter excreted by a mixotrophic flagellate during bacternvory and autotrophy. Appl environ Microbiol 60:1884-1888

Vaqué D, Gasol JM, Marrasé C (1994) Grazing rates on bacterka. the significance of methodology and ecological factors. Mar Ecol Prog Ser 109:263-274

Wells ML, Goldberg ED (1991) Occurrence of small colloids in sea water. Nature 353:342-344

White PA, Kalff J, Rasmussen JB, Gasol JM (1991) The effect of temperature and algal biomass on bacterial production and specific growth rate in freshwater and marine habitats. Microb Ecol 21:99-118

Manuscript first received: June 6, 1995

Revised version accepted: September 25, 1995 